研究速報

\title{
大分川におけるふん便性細菌と土地利用の相関分析
}

\section{Correlation Analysis between Fecal Bacteria and Land Use Data in Oita River}

\author{
平岡透*・高見 徹*・古川 隼士*・野中 尋史** \\ Toru HIRAOKA, Toru TAKAMI \\ Takashi FURUKAWA and Hirofumi NONAKA
}

\begin{abstract}
We analyze and evaluate a correlation between fecal bacteria (Escherichia coli, fecal indicator bacteria and enterococci) and land use data for each month in the Oita River Basin. In these calculations, we consider the optimal range based on land use data from the observation points of the fecal bacteria. As a result of the analysis, we found that the correlation of agricultural land expect rice field is high in land use, and the correlations of the fecal bacteria are high in the case of using land use data from 400 to $500 \mathrm{~m}$ radius.
\end{abstract}

Keywords：土地利用，子ん便性細菌，相関分析

\section{1.はじめに}

河川は水遊びや釣りなどの親水空間として利用さ れ, 河川水は農業用水, 工業用水, 水道用水, 雑用水 などとして利用されていることから，河川水の污染は 人の健康にとって極めて深刻なリスクとなる可能性が あり，実際に重金属や農薬，有機塩素化合物などの他 にふん便性細菌による河川水の污染が大きな問題と なっている(大瀧，2001；金子，2006)。そのため，日 本では環境基準における衛生指標として大腸菌群が採 用されており，関係省庁の国土交通省において毎年一 級河川の大腸菌群数のモニタリングが行われている （国土交通省，2014）。また，大腸菌群の発生源の追跡 も重要な課題であるため, 課題解決のための基礎調查 として大腸菌群数と土地利用の相関分析を行う研究も 行われている(平岡ら，2014)。しかしながら，大腸菌 群には自然由来の細菌も多く含まれているため，環境 省では大腸菌を新たな環境基準として採用することが 検討されている(環境省，2011)。大腸菌は，動物の腸

* 大分工業高等専門学校

**長岡技術科学大学

「写真測量とリモートセンシング」VOL. 55，NO. 1， 2016
管内に常在する腸内細菌群の一つであり, 自然界では 増殖できないため, 河川や湖沼などの公共用用水にお けるふん便污染の指標の一つとして有望視されてい る。

そこで本稿では，環境基準の変更を踏まえて，病原 性微生物による水系感染のリスクの指標として，欧米 を中心に広く用いられているふん便性細菌群の大腸 菌，ふん便性大腸菌，腸球菌を対象に大分県を流れる 一級河川である大分川に扔いて調查を実施し，各細菌 数と土地利用の相関分析を行う。大分川でのこれらの ふん便性細菌の調查の結果は，筆者らが既に報告して いる（古川ら，2015）。古川らの文献（2015）のふん便 性細菌数を用いて土地利用との相関分析を行った。土 地利用の項目として, 田, 田以外の農用地，森林，建 物用地，河川地・湖沼の 5 項目を取り上げた。さらに， 土地利用データとしてふん便性細菌の観測地点から任 意の半径に含まれる土地利用の割合を用いるが，ふん 便性細菌数との相関が高くなる半径も調べた。本研究 の成果は，2006年11月に国土交通省によって策定され た大分川水系河川整備計画（国土交通省九州地方整備 局，2006）を将来変更するにあたり，大腸菌数の数值 目標を定めるための基礎資料になると考えられる。ま た, 大腸菌数, ふん便性大腸菌群数, 腸球菌数と土地 利用の関係が明らかになれば，ふん便性細菌による発 
生源の追跡における特定範囲を絞り込むことが可能と なり, 将来の健全な水循環を考慮した流域計画のため の基礎資料になるとも考えられる。

\section{2. 調査方法}

\section{1 調査対象}

本研究では，大分県を流れる大分川を調查フィール ドとする。大分川は，その源を大分県由布市湯布院町 の由布岳 (標高 $1,583 \mathrm{~m}$ ) に発し, 由布院盆地を貫流し, 阿蘇野川や芹川などを合わせて中流の渓谷部を流下 し，由布市狭間町に扔いて大分平野に入り，賀来川と 七瀬川を合わせて, 大分市豊海において別府湾に注ぐ, 幹川流路延長 $55 \mathrm{~km}$ ，流域面積 $650 \mathrm{~km}^{2}$ の一級河川であ る。大分川流域の土地利用は，山地などが約 $84 \%$ ，水 田や畑地などの農地が約 $11 \%$ ，宅地などの市街地が約 $5 \%$ である。大分川および支川の大臣管理区間におけ る河川水の利用状況（許可水利権平成 17 年 3 月現在） は, 農業用水 $1.247 \mathrm{~m}^{3} / \mathrm{s}$, 工業用水 $0.174 \mathrm{~m}^{3} / \mathrm{s}$, 水道用 水 $1.250 \mathrm{~m}^{3} / \mathrm{s}$, 雑用水 $0.028 \mathrm{~m}^{3} / \mathrm{s}$ であり, 大分市の水道 用水は大分川に大きく依存している。

本研究では, ふん便性細菌として大腸菌, ふん便性 大腸菌群，腸球菌を取り上げる。以下，子ん便性細菌 と言えば，大腸菌，ふん便性大腸菌群，腸球菌を指寸 ことにする。ふん便性細菌は, 図 1 に示す大分川の 17 地点で観測を行った。観測地点は，上流から下流に向 かって 1 から17と番号付けた。17地点において，2013 年12月から2014年11月に毎月一回の合計12回の観測を 行った。ふん便性細菌数の測定方法などの詳細は, 古 川らの文献（2015）を参照されたい。

\section{2 相関分析の方法}

大腸菌数, ふん便性大腸菌群数, 腸球菌数と相関分

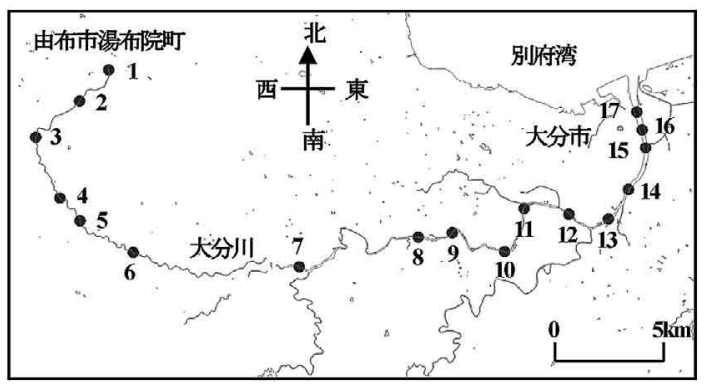

図 1 病原性細菌の観測地点
析を行う土地利用区分として，田，田以外の農用地， 森林，建物用地，河川地・湖沼の 5 項目を取り上げた。 土地利用のデータは，国土数值情報土地利用細分メッ シュデータ(国土交通省国土政策局国土情報課，2014) を用いた。国土数值情報土地利用細分メッシュデー夕 は, 3 次メッシュを東西㧍よび南北方向に 10 分割した $100 \mathrm{~m}$ メッシュ毎に土地利用区分を整備したものであ り, 実験では2009年時点のものを用いた。各土地利用 デー夕は，各観測地点において任意の半径に含まれる 割合とした。半径は, $300 \mathrm{~m}, 400 \mathrm{~m}, 500 \mathrm{~m}, 600 \mathrm{~m}, 700$ $\mathrm{m}$ の 5 通りで実験を行った。ふん便性細菌数は季節に よって大きく変動するが，土地利用は数年で大きく変 動することは少ないと考えられるため, ふん便性細菌 数と土地利用の相関分析は月ごとに行った。

具体的な子ん便性細菌数と土地利用の相関分析の方 法を次に示す。 $m(=1,2, \cdots, 12)$ 番目の月に $n(=1,2$, $\cdots, 17)$ 番目の地点で観測された大腸菌数 $(k=1)$, ふん 便性大腸菌群数 $(k=2)$, 腸球菌数 $(k=3)$ をそれぞれ $T_{k, m, n}(k=1,2,3)[\mathrm{MPN} / 100 \mathrm{~mL}]$ とする。また, $n$ 地 点から半径 $d[\mathrm{~m}]$ 以内に含まれる各土地利用区分 (田 $(l=1)$, 田以外の農用地 $(l=2)$, 森林 $(l=3)$, 建物 用地 $(l=4)$, 河川地・湖沼 $(l=5))$ の割合をそれぞ れ $L_{l, n, d}(l=1,2, \cdots, 5)[\%]$ とする。 $m$ 番目の月の各 了几便性細菌数 $T_{k, m, n}$ と半径 $d$ に打ける各土地利用 区分の割合 $L_{l, n, d}$ の平均をそれぞれ $\bar{T}_{k, m}$ と $\bar{L}_{l, d}$ とす ると, 相関係数 $E_{k, l, m, d}$ は, 以下の式で求まる。

$$
E_{k, l, m, d}=\frac{\sum_{n=1}^{17}\left(T_{k, m, n}-\bar{T}_{k, m}\right)\left(L_{l, n, d}-\bar{L}_{l, d}\right)}{\sqrt{\sum_{n=1}^{17}\left(T_{k, m, n}-\bar{T}_{k, m}\right)^{2}} \sqrt{\sum_{n=1}^{17}\left(L_{l, n, d}-\bar{L}_{l, d}\right)^{2}}}
$$

\section{3. 調査結果と考察}

\section{1 病原性細菌数の測定結果と考察}

大腸菌数, ふ九便性大腸菌群数, 腸球菌数を測定し た結果をそれぞれ図 2 から図 4 に示す。図 2 から図 4 の縦軸がふん便性細菌数 $[\mathrm{MPN} / 100 \mathrm{~mL}]$, 横軸が地点 番号である。図 2 より, 上流ほど大腸菌数が多く, 特 に地点 1 と地点 2 で大腸菌数が多くなる傾向があるこ とがわかる。図 3 より, 上流ほどふん便性大腸菌群数 が多く, 地点 2 , 地点 7 , 地点14あたりでふん便性大 腸菌群数が多くなる傾向があることがわかる。また, 12 月に扮ける地点 8 , 地点 9 , 地点 $11 の$ 子几便性大腸 


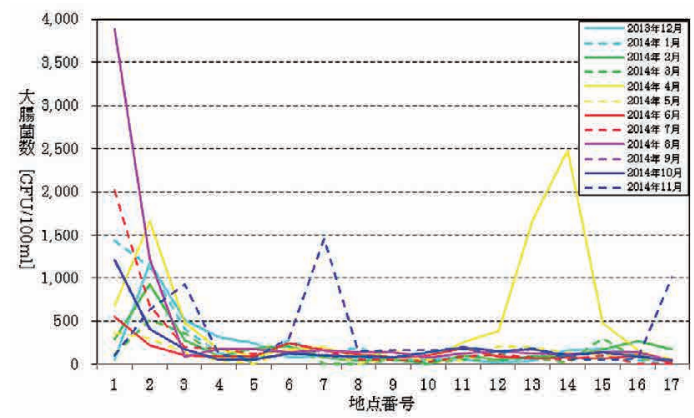

図 2 各観測地点の大腸菌数

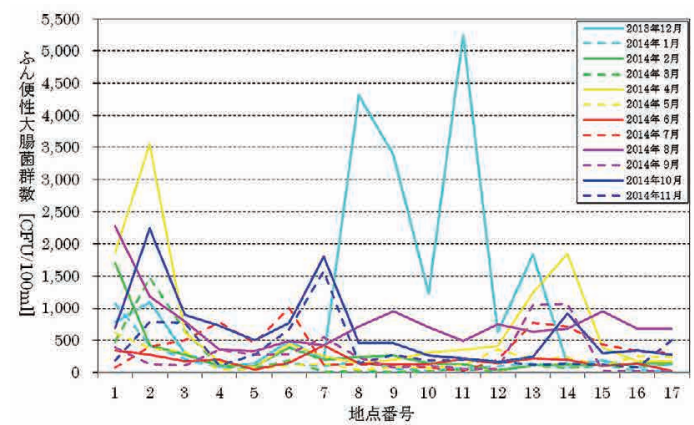

図 3 各観測地点のふん便性大腸菌群数

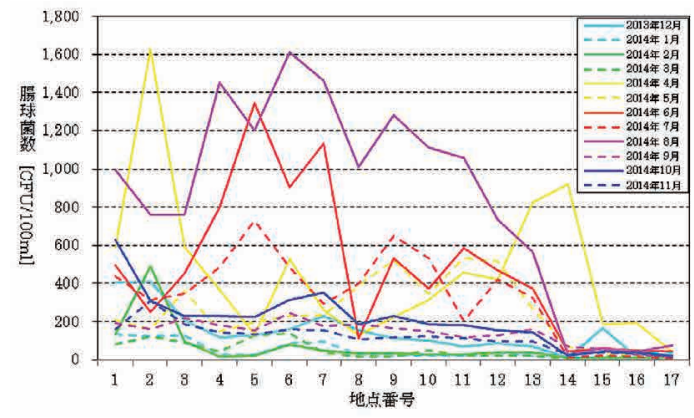

図 4 各観測地点の腸球菌数

菌群数が極端に多くなっていることがわかるが，この 理由を現地調查や複数年の観測によって調べる必要が ある。図 4 より，上流ほど腸球菌数が多く，4 月から 8 月に腸球菌数が多くなる傾向があることがわかる。 全体的に，上流ほどふん便性細菌数が多く，特に地点 1 と地点 2 でふん便性細菌数が多くなる傾向があるこ とがわかる。

\section{2 相関分析の結果と考察}

まず, 大腸菌数, ふん便性大腸菌群数, 腸球菌数に 対して，2013年12月から2014年11月の月ごとに相関分 析をそれぞれ行った。このとき，田，田以外の農用地， 森林, 建物用地, 河川地・湖沼の 5 項目の土地利用区
分の割合は, 半径 $d$ を後の実験で比較的高い相関が得 られた $400 \mathrm{~m}$ として求めた。大腸菌数, 子ん便性大腸菌 群数，腸球菌数と土地利用との相関分析の結果をそれ ぞれ図 5 から図 7 に示す。図 5 から図 7 の縦軸が相関 係数，横軸が年月である。図 5 より，大腸菌数と田以 外の農用地に一年を通して比較的高い正の相関があ り，特に12月から 5 月の間に正の相関が高くなること がわかる。また， 5 月から 10 月の大腸菌数と建物用地 に比較的高い正の相関が，6月から 10 月大腸菌数と河 川・湖沼に比較的高い負の相関があることがわかる。 図 6 上り，3 月，4 月，11月の子ん便性大腸菌群数と 田以外の農用地に高い正の相関を示しているが，その 他にふん便性大腸菌群数と相関のあるような土地利用

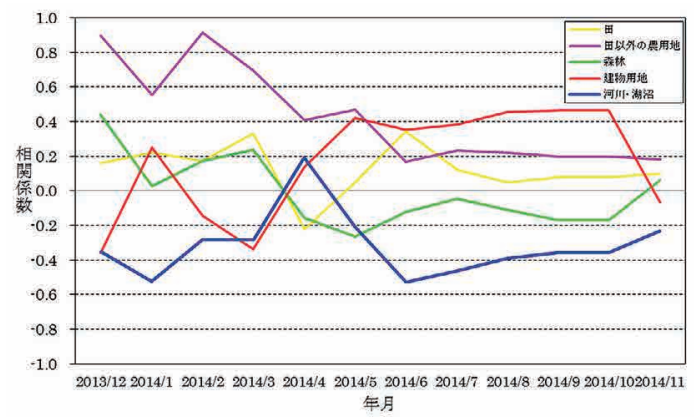

図 5 大腸菌数と土地利用の相関係数

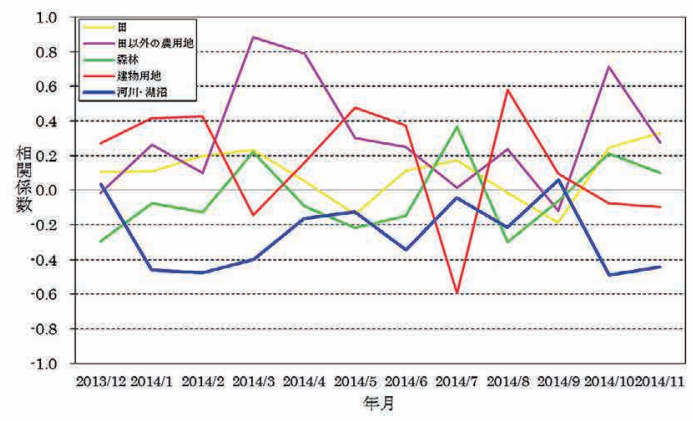

図 6 ふん便性大腸菌群数と土地利用の相関係数

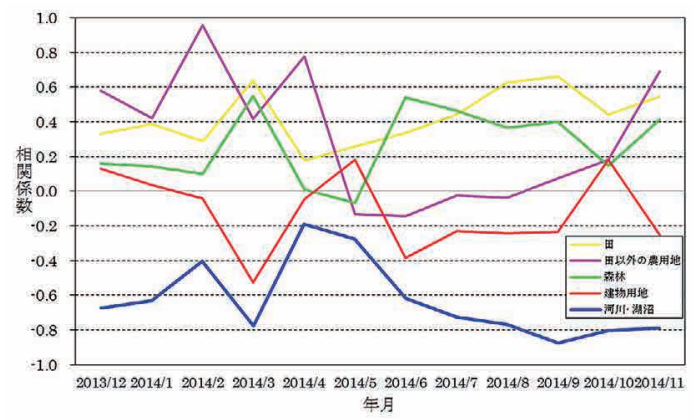

図 7 腸球菌数と土地利用の相関係数 
区分はない。図 7 より，腸球菌数と田に一年を通して 比較的高い正の相関があることがわかる。また，11月 から 5 月の腸球菌数と田以外の農用地に高い正の相関 が， 6 月から 3 月の腸球菌数と河川・湖沼に高い負の 相関があることがわかる。全体的に，冬場のふん便性 細菌と田以外の用地に比較的高い正の相関を示す傾向 があることがわかる。この理由として，子ん便性細菌 数が比較的多い上流部の地点 2 の田以外の農用地の割 合は半径 $d$ が $400 \mathrm{~m}$ の場合で $6.4 \%$, ふん便性細菌の少 ない最下流部の地点17の田以外の農用地は半径 $d$ が $400 \mathrm{~m}$ の場合で存在しなかったように，上流部の農村 地域でふん便性細菌数が多く, 下流部の都市部でふん 便性細菌数が少なく測定されたことに起因すると考え る。地点 2 は温泉地である由布市湯布院町であり, 温 泉水や温泉排水の流入がこのような傾向を示す要因に なったと推測する。

次に，半径 $d$ を $300 \mathrm{~m}, 400 \mathrm{~m}, 500 \mathrm{~m}, 600 \mathrm{~m}, 700 \mathrm{~m}$ と変えて, 比較的高い正の相関を示した 2 月の大腸菌 数, 3 月の子ん便性大腸菌群数, 2 月の腸球菌数と田 以外の農用地との相関分析を行った。この結果を困 8 に示す。困 8 の縦軸が相関係数, 横軸が半径 $d[\mathrm{~m}]$ で ある。図 8 より, 半径 $d$ が $400 \mathrm{~m}$ から $500 \mathrm{~m}$ で比較的高 い相関を示すことがわかる。

最後に, 半径 $d$ が $400 \mathrm{~m}$ の場合で, 2 月の大腸菌数, 3 月のふん便性大腸菌群数, 2 月の腸球菌数と田以外 の農用地との相関分析の $t$ 検定を行った。この結果得 られた大腸菌数, ふん便性大腸菌群数, 腸球菌数の $t$ 值 は，それぞれ7.3，8.7，12.9であった。有意水準0.1\%

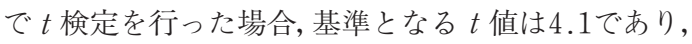
各ふん便性細菌数の $t$ 值はいずれも 4.1 よ大きいの で, 有意水準 $0.1 \%$ でふん便性細菌数と田以外の農用地 に相関関係があるといえる。

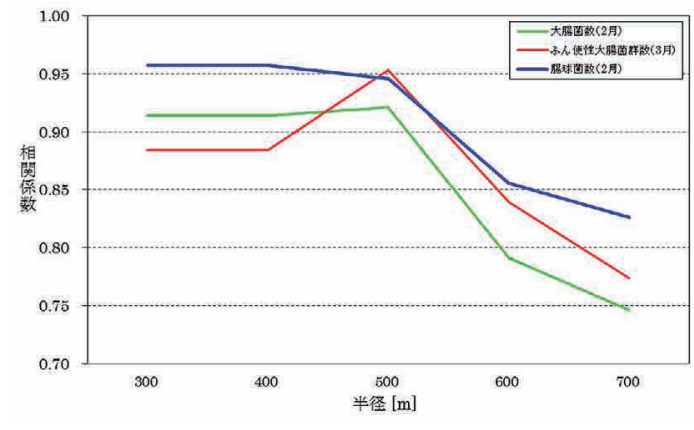

図 8 半径 $\boldsymbol{d}$ による相関係数

\section{4.おわりに}

大分川の大腸菌, ふん便性大腸菌群, 腸球菌のふん 便性細菌を調査し, ふん便性細菌数と土地利用の相関 分析を行った。相関分析の結果, 冬場のふん便性細菌 数と田以外の農用地に比較的高い正の相関を示す傾向 があることがわかった。この理由は, 大分川上流の温 泉地での温泉水と温泉排水の影響を受けているためで あると推測する。また, 半径が $400 \mathrm{~m}$ から $500 \mathrm{~m}$ に含ま れる田以外の農用地の割合を用いた場合に, ふん便性 細菌数と比較的高い相関を示すこともわかった。この 理由は, 堆肥などに存在するふん便性細菌の影響があ るのではないかと推測する。

今回はふん便性細菌を 1 年間観測して相関分析を 行ったが，ふん便性細菌を複数年観測しデー夕を増や して相関分析を行うことが今後の課題である。また， 12 月における地点 8 , 地点 9 , 地点 11 の子ん便性大腸 菌群数が極端に多くなっている理由を現地調査や複数 年の観測によって調べることも今後の課題である。環 境省では大腸菌を新たな環境基準として採用すること が検討されており, 大腸菌などのふん便性細菌と土地 利用の相関分析を行うことで, ふん便性細菌の発生源 の追跡に役立つと考えられる。

(受付日2015.12.14, 受理日2016.1.7)

\section{参考文献}

大瀧雅寛，2001. 水環境における病原微生物の実態と 水質基準, 生活工学研究, Vol. 3 , No. 2, pp.162-169. 金子光美, 2006. 水の安全性と病原性微生物一その歴 史と現状，そして未来，モダンメディア，Vol. 52， No. 3 , pp.76-82.

国土交通省，2014. 水文水質データベース，http:// www1.river.go.jp.

平岡 透, 野中尋史, 2014. 大腸菌群数と土地利用の 相関分析, 写真測量とリモートセンシング, Vol. 53, No. 2, pp.62-66.

環境省, 2011. 今後の取組の進め方について, https:// www.env.go.jp/water/confs/fpwq/torimatome2/ 04.pdf.

古川隼士，野中尋史，平岡 透，高見 徹，亀野辰三， 2015. 大分川におけるふん便性污染に関する細菌学 的調査, 水環境学会誌, Vol. 38, No. 6, pp.173-180. 
国土交通省九州地方整備局，2006。大分川水系河川整 備計画, http://www.qsr.mlit.go.jp/oita/kasen-sei bi/h18.10/honbun.pdf.
国土交通省国土政策局国土情報課，2014.GIS ホーム ページ, http://www.mlit.go.jp/kokudoseisaku/ gis/index.html. 